\title{
BELÉNYI GYULA: AZ ALFÖLDI VÁROSOK ÉS A TELEPÜLÉSPOLITIKA (1945-1963)
}

\author{
(Csongrád Megyei Levéltár, Szeged, 1996 - p. 211)
}

\section{BARANYI BÉLA}

Tudományosan fontos, egyszersmind aktuális munka kiadására vállalkozott a Csongrád Megyei Levéltár, amikor a méltán rangos Dél-Alföldi Évszázadok címü sorozat 7. köteteként megjelentette Belényi Gyula, sok vonatkozásában hiánypótló könyvét. A Nagyalföld Alapitvány, az MTA Szegedi Területi Bizottsága és a Szeged Város Önkormányzata támogatásával napvilágot látott kötet nemcsak tiszteletre méltó tudományos teljesitményével, igényes formai kivitelezésével, esztétikus borítójával tarthat igényt széleskörü szakmai érdeklődésre, hanem a témaválasztás időszerüségével is, amely alapvetöen történeti indíttatású munka esetében különösen figyelmet érdemel. A könyv jól példázza a történeti elemzések által feltárt és a jelenben is zajló folyamatok szoros összetartozását, a múltbeli és a jelenkori változások ok-okozati összefüggéseit.

Kerülve bármiféle erőltetett aktualizálásnak és prezentizmusnak még a látszatát is, az elöbbi megjegyzések elörebocsátását azért tartottuk fontosnak, mert egy történeti összefüggésekbe ágyazott, jórészt településpolitikai kérdéseket vizsgáló munkának számos üzenete lehet - és van - a napjaink nagyhorderejü terület- és településfejlesztési politikáját, a gazdasági-társadalmi tér és a településhálózat rejtettebb, regionális nagy- és kistérségi összefüggéseit, jövőjét tervező- alakító elméleti és gyakorlati szakemberek számára. A magyarországi rendszerváltás nyomán megindult sokirányú átalakulási folyamat velejárójaként ugyanis megszaporodtak a területi tudományok publikációi, szélesebb körben váltak ismertté a területi politika változó és meg-megújuló elvei. Jelenleg lépett a gyakorlati megvalósítás stádiumába a nemrég elfogadott Nemzeti Területfejlesztési Törvény, most formálódik Országos Területfejlesztési Koncepció és számos egyéb a térség- és a területfejlesztést, valamint a településhálózat fejlesztési irányait érintő elképzelés.

Nehéz lenne elhallgatni, hogy a hat megyét magában foglaló Alföld gazdaságában és társadalmában a rendszerváltás elótt lejátszódott, s az azóta zajló folyamatok távolról sem kedvezőek a térségnek a fejlettebb régiókhoz (Budapest, ÉszaknyugatNyugat-Dunántúl) történő felzárkóztatása számára. Számos jel mutat arra, hogy a régtöl fogva meglévő távolságok tovább nőnek, sőt érdemi változás hiányában a visszafordíthatatlan leszakadás, a területi periferizálódás veszélye fenyeget kiterjedt alföldi területeket, nagy- és kistérségeket egyaránt. Egy-két kistérségtöl eltekintve az alföldi megyék jelenleg is az ország leghátrányosabb helyzetü tájegységei-régiói közé tartoznak. A tét igen nagy, csak a hat alföldi megyében, az ország területének mintegy $40 \%$-án az össznépesség közel egyharmada él. Belényi Gyula könyve többek között éppen a konzerválódott és újratermelödött hátrányos helyzet történeti, gazdasági-társadalmi előzményeire irányítja rá a figyelmet. 
A szerző jó érzékkel választotta meg témájảt, hiszen az Alföldön történelmileg kialakult sajátos telepulésrendszer múltjának és jelenének a vizsgálata már tőbb tudományág hazai és külföldi tudósainak az érdeklödését is felkeltette. Belényi a magyarországi nagyrégió városaiban, illetóleg a funkcionálisan városnak tekinthetó 10 ezer lakosnál népesebb településein (agrárvárosaiban) a második világháborútól a paraszti társadalmat megrázkódató tơmeges kollektivizálás befejezéséig tartó közel két évtized gazdasági és társadalmi változásait elemzi egy hosszabb történeti folyamatba illesztve. Az 1945 elötti elözmények viszonylag részletes vizsgálatával nemcsak a történetiség elvének igyekezett eleget tenni, hanem megítélhetővé kivánta tenni, hogy az 1945-1963 közötti korszak változásaiból mi tekinthető egy hosszabb ideje tartó történeti tendencia kifejeződésének, illetve folytatásának, és mi eredeztethető döntően az elemzett időszak sajátos politikai, társadalmi-gazdasági viszonyaiból. (A történeti elöfeltételek bemutatására " $A z$ örökség: $a$ kapitalizmuskori városfejlódés mérlege " címü elsö és "A megújulás esélyei és korlátai a második világháború után " címủ második fejezetben kerül sor.)

A könyv legföbb érdeme, hogy sikeresen valósítja meg benne a szerzó azt a nyilvánvaló tudományos célt, hogy feltárja és bemutassa a sajátságos alföldi településtípusban élö, az 1940-es végén már több, mint másfél milliós összlélekszámú helyi társadalmak reagálását azokra az 1945 utáni viharos politikai, gazdasági, társadalmi és urbanizációs változásokra, amelyek gyökeresen átalakitották a városfejlödés feltételeit Magyarországon. $\mathrm{Az}$ alapvetően társadalomtörténeti-várostörténeti jellegü kutatási feladat, a negyvenes évek végére kialakult politikai rendszer sajátosságaira való tekintettel, csak úgy volt teljesithetö, hogy ha bemutatja az 1949-1963 közötti országos terület- és telepúlésfejlesztési politika történetét, illetôleg annak a regionális hatásait is. Aligha véletlen, hogy a könyv mind tartalmában, mind terjedelmében legtekintélyesebb, $\mathrm{s}$ kétségkivül legfontosabb, egyszersmind legszinvonalasabban megirt, itt-ott lebilincselóen érdekes és olvasmányos része "A városfejlódés politikai feltételeinek gyökeres átalakulása 1948 utăn" címet viselŏ harmadik fejezete.

Az öt részre tagolt, széles forrásbázisra épülö fejezetben az 1949 és 1953 közötti felulről vezényelt, $s$ meglehetösen önkényes terület- és településfejlesztési politika törekvéseit, a szovjet gyakorlatból átvett rajonirozási terveket, az igazgatási reformtervekre és modernizációra vonatkozó különféle elképzeléseket, valamint az 1957-1963 közötti településpolitikai korrekciókat mutatja be és értékeli a szerzö. Ebben a fejezetben markánsan jut kifejezésre a könyv egyik alapgondolata, hogy az alföldi (agrár) városok egy dinamikus növekedési szakaszba csak a gazdasági funkciók megújulásával léphettek volna, amely ebben az idöszakaszban egyet jelentett volna az iparosodással. Ám az utóbbi csak fölöttébb tétován, felemásan és ellentmondásosan érintette az alfơldi városokat. Mi sem jellemzöbb a kialakult, mármár anakronisztikus helyzetre, hogy a hatalmas volumenü, extenziv iparositás "höskorában", az első ötéves terv idôszakában (1950-1954) az ország összes beruházásainak csupán 7,3\%-a, de az évtized végén is kevesebb, mint $10 \%$-a jutott az ország területének mintegy kétötödét elfoglaló és a lakosság 33\%-ának otthont adó Alfóldre, miközben az új munkahelyek 50 százaléka Budapesten létesưlt.

Nyilvánvaló tehát, hogy 1950 és 1963 között a régióba irányuló mezőgazdasági, az ipari és az egyéb beruházások összege nem volt arányban az érintett megyẹ́k által 
a nemzeti jövedelemből megtermelt értékek nagyságával. A túlnyomórészt agrár jellegũ régióban a városok - a kisebb telepưlésekről nem is szólva -, urbanizációs infrastrukturális és kommunális fejlesztésének a rovására végbement feszített és eröltetett ütemü extenzív, egyszersmind aszimmetrikus, Budapestre és néhány vidéki nagyvárosra irányított iparosítás olyan "túlurbanizációs" folyamatot eredményezett, amely legalább ennyire "alulurbanizációs" tendenciákat is magában hordozott. A korabeli terület- és településfejlesztési politika a beruházások koncentrálására törekedve a rendelkezésre bocsátott beruházási erőforrásokat csak egy-két város vagy kiemelt központ (elsősorban a megyeszékhelyek) fejlesztésére fordította, a telepulések többségét, köztük az alföldi agrărvárosokat gyakorlatilag hanyatlásra kárhoztatta. Mindez számottevően hozzájárult az Alföldön a területi egyenlốtlenségek és hátrányok akkumulációjához, kiterjedt térségek marginalizálódásához, a városfejlődés ütemének "késleltetéséhez".

A könyv egyik jelentős tudományos eredménye éppen az, hogy az 1948-1963 közöttti településpolitika történetének elemzésével feltárja az alföldi, elsősorban agrárvárosok fejlödésére gyakorolt, zömmel kedvezőtlen következményeket. A szerzö részletekbe menően tárgyalja és követi végig azt a folyamatot, amelyben a különbözoó terület- és területfejlesztési koncepciók és maga, a negyvenes évek végétôl egyoldalúvá és szélsôségessé torzult politikai (irányítási) gyakorlat, a "magasba szárnyalo" gazdaságpolitikai céloknak, az erőltetett uttemü, extenzíves voluntarista iparositás koncepciójának vetették alá a településfejlesztés kérdését, különösen ami a történelmileg kialakult sajátosságokkal bíró (tágas határ, nagy kulterületi népesség, tanyás megtelepedés, magas paraszti hányad a helyi társadalmon belül) alföldi városokat, agrárvárosokat illette. A szerteágazó kérdéskörből máig ható következményei és számos aktualitása (pl. a demokratikus önkormányzatóság megteremtése) miatt az alföldi telepuulésviszonyok szempontjából rendkívül fontos, ám a "fordulat éve" utáni monolitikus politikai rendszer viszonyai között kudarcra itéltetett reform elképzelések közül különösen két probléma, a tanyakérdés (községesitési politika) és a "városmegyés" közigazgatási modell részletes kifejtésével és bemutatásával számíthat ma is közérdeklödésre a könyv.

A népesség területi megoszlásával kapcsolatos problémák közül az alfölditiszántúli teruletek legégetóbb gondja hosszú ideig a tanyakérdés volt. A 40-es évek legvégén a kor vezető igazgatáspolitikusai részéröl már határozott koncepciók születtek a tanyakérdés "végleges megoldására", a "tervgondolkodást akadályozó" településtípus felszámolására. A magyar tanyarendszer átalakításának, illetỏleg felszámolásának elősegítésére hozták létre 1949 februárjában az Országos Tanyai Tanácsot, amely a probléma megoldását nagyarányú beruházásokkal, állami rendszabályokkal (a tiltás és támogatás eszközeivel) az általános tanyaközpontosításban és községesitésében, vagyis a szétszórt telepưlések felszámolásában, egyes tanyaközpontok községi rangra emelésében látta. Mindez föleg a szükebb értelemben vett tanyás vidékekre, az alföldi megyékre terjedt volna ki. A tervezett 242 tanyaközpontból mintegy 200 létesullt az Alföld másfélmillió holdnyi területén, közvetlenưl érintve a kủlterületi lakosság 300-350 ezres tömegét.

A kétségkívül nagyvonalú, de erőszakolt elképzeléseknek azonban hiányoztak a társadalmi-gazdasági feltételei, $\mathrm{s}$ az érintett tanyai népesség vonakodott tőlük. $\mathrm{Az}$ 
Alföldön történetileg egyébként anorganikus, a tanya és a város közötti átmeneti formára, a tanyaközpontok létesitésére irányuló tervek érthető módon nem realizálódtak. Ilyen körülmények között 1952-53-ra nemcsak a tanyaközpontok létesítése és fejlesztése maradt el, hanem megszünt az Országos Tanyai Tanács is. "Mindössze" annyi történt - persze ez nem kevés -, hogy a tanyák társadalmának mobil eleme, ha éppen a mezőgazdaság szocialista szektorába nem lépett át, részben a nincstelen sorból szabadulás igényével, részben gazdaságát és a paraszti sorsot feladva, a "szocialista iparosítás" révén az idő tájt bőven kínálkozó városi munkát keresett magának, ingázott vagy pedig végleg elvándorolt a tanyáról.

Az 1945 és 1950 között megfogalmazott igazgatási reformtervek, modernizációs elgondolások, illetöleg a már kidolgozott igazgatási reformok közül az alfôldi településviszonyok szempontjából a Bibó István és Erdei Ferenc által képviselt, a Nemzeti Parasztpárt nevében tett javaslat érdemel megkülönböztetett figyelmet. E "városmegyés" igazgatási reformterv modelljéül ugyanis éppen az alföldi tanyás városok szolgáltak (a tervbe vett városmegyék közel fele, számszerint 41 az Alföldre esett volna). A Bibó István által kezdeményezett kőzigazgatási modell az ország akkori 25 vármegyéje és 151 járása helyett 98 városmegyére akarta osztani az országot (azokon a vidékeken ahol még nem alakultak ki a városok, ott az arra legalkalmasabb, központi helyen fekvő községek várossá fejlesztésével). Ezek fölött középsỏ igazgatási (afféle "tartományi") szintként hét országos területet akart létrehozni, ami térben szétosztotta volna a központi hatalmat, illetve államigazgatást. A tervezet egyik, központi gondolata tehát a közigazgatás egyszerüsitése és decentralizáciỏja volt. Nem nehéz észrevenni hasonló törekvéseket a mai regionális, kistérségi fejlesztési stratégiák és programok kidolgozása során, például a hat nagyrégiós területi statisztikai tervezési egység, a NUTS II és a 138 kistérségi statisztikai körzet és az önkormányzatiság rendszerváltás utáni megerősődése kőzött) Helyesen hangsúlyozza a szerző, hogy "...Bibóék elgondolásának az egyik leglényegesebb eleme: az ország társadalmát úgy kívánták bekapcsolni az urbanizációs és egyben a polgárosodási folyamatokba, hogy közben ne rombolódjanak szét a helyi társadalmak, az ott élök ne kényszerüljenek tömegesen elvándorolni és egyetlen (esetleg néhány) nagyvárosba tömörülni, hanem megfelelő gazdasági feltételekkel párosulva maguk a helyi társadalmak urbanizálódjanak és polgárosodjanak." (111-112. o.).

Könnyü belátni, hogy megvalósulása esetén ez a koncepció milyen nyereség lehetett volna az alföldi települések fejlődése szempontjából.

A szerzỏ új összefuggések felvillantásával kíséri végig azt a folyamatot, amelynek végeredményeként a mélyen demokratikus elkötelezettségũ, a helyi társadalmak érdekeit elötérbe helyezö reformterv, a városi és a városkörnyéki társadalom "egybeszervezését" célzó elgondolás, noha kezdetben taktikai megfontolásból az MKP is támogatta, I947 után immáron elvi okok miatt szükségszerũen futott zátonyra a baloldali erốk gyózelmét elörevetítő politikai küzdelmek sodrában. A sajátos magyarországi viszonyokra kidolgozott városmegyés jovaslat keresztezhette volna ugyanis az "úgynevezett önkormányzatisággal" a demokratikus centralizmus doktrínáját szembeállító proletárdiktatúra, monolitikus jellegũ politikai rendszerének a kiépitését, amelynek "osztályharcos" felfogásával nem volt összeegyeztethetố a demokratikus önkormányzatiság eszméje. Az 1950-ben szovjet 
mintára megvalósított megyereform és az ugyanekkor bevezetett tanácsrendszer a központi és a helyi hatalom viszonyában az elöbbi abszolút túlsúlyát jutatta érvényre.

Végül Belényi Gyula elismerésre méltó eredményeket ért el könyvének "A gazdaság és társadalom 1948-1963" címet viseló zárófejezetében az alföldi agrárvárosok gazdasági alapfunkcióinak a változásával összhangban zajló társadalmi átalakulási folyamatok ábrázolása, a társadalmi-foglalkoztatási átrétegződés bemutatása, illetőleg a szélesebb értelemben vett társadalmi struktúraváltozás föbb jellemzőjének a leirása terén is. A szerzö különösen nagy súlyt helyez a paraszttársadalom gyötrelmes átalakulásának a bemutatására, feltárva többek között a gazdagparaszti réteg lesüllyedésének, valamint az Alföldön, beleértve a városok nagy részét is, az 1949-1963 között elszenvedett hatalmas vándorlási veszteségnek az okait és következményeit. Az egyidejúleg lejátszódott gyors ütemü foglalkozási átrétegzôdés eredményeként a tízezernél népesebb alfơldi települések mezögazdasági népesség aránya a például az 1949. évi 53\%-ról 1970-ig $28 \%$-ra csökkent.

A gazdasági és társadalmi-strukturális viszonyok változásai alapján joggal jut el a szerzö a végsö következtetésig, hogy az 1945 és 1963 közötti idöszakban az alföldi (agrár) városok történelmi eredetủ sajátosságai halványodtak ugyan (agrárvárosi jelleg, nagy határ, jelentös külterület és tanyás népesség stb.), ám az öröklött vonások tóvolról sem tüntek el. $\mathrm{Az}$ agrárjellegtól való távolodás a korábbi várakozásokkal és politikai ígéretekkel ellentétben, nem vonta maga után a települések gyors urbanizációját és polgárosodását, következésképpen az ország fejlettebb részeihez való felzárkózását sem. Tovább folytatva a szerzö gondolatmenetét könnyủ felismerni benne a halmozottan hátrányos helyzet, a területi egyenlö́tlenségek kialakulásának, a társadalmi-gazdasági leszakadás történelmi elözményeit és okait.

Összességében Belényi Gyula munkája a megújuló regionális történetírás egyik széles forrásbázisra támaszkodó, (színvonalas) tudományos eredménye, az Alfoldkutatás méltán jelentős teljesitménye. A könyv egyszersmind fontos adalék a ma is meglévő súlyos területi egyenlőtlenségek és hátrányok történeti, gazdaságitársadalmi és politikai elózményeinek a tanulmányozásához. Témája és interdiszciplináris jellege miatt egyaránt számíthat a történettudomány, a társadalomtörténet, a társadalom- és telepulésfơldrajz, s nem utolsó sorban pedig a területfejlesztés kérdéseivel foglalkozó elméleti és gyakorlati szakemberek - és olvasók - érdeklődésére. 